\title{
The Activity of 1,3,4 Thiadiazole Derivatives on the Soluble Oils
}

Khalid W.Y.Zain Alabdeen, Al-nahrain university, College of Science,Chemistry Department, Al-jadyriah, Baghdad,Iraq

\section{Abstract:}

That Thiadiazoles derivative is biologically active as antimicrobial agents in cooling fluids.

Derivatives of 1, 3, 4- thiadiazole have prepared:

1- 2-amino-3-[(2-amino-1, 3, 4-thiadiazol-5-yl) dithio] propanoic acid.

2- 2-(2-Carbethoxyamino-1, 3, 4-thiadiazol-5-yl)-thio acetic acid.

3- [(5-amino-1,3,4-thiadiazol2-yl) dithio] acetic acid

The synthesized compounds have been used as antimicrobial against the microorganisms which have been found in the cooling fluid of industrial purposes by using media culture the results showed that the compounds 1 and 3 are relatively highly active in killing bacteria from the compound 2 .
The $\mathrm{pH}$ of the cooling fluid samples had been measured after the addition of salt media as well as the inhibitors $(1,2,3)$ the results of $\mathrm{pH}$ measurement revealed that the compounds 1,2 and 3 exhibit high activity to inhibit the growth of bacteria.

The turbidity for such media and inhibitors has also been measured and the results indicated that 1,2 and 3 have given low turbidity to inhibit the bacteria or the microorganisms that grow in the cooling fluid.

\section{Introduction:}

Cooling fluids are played an important role in the industrial processes through metals cutting. 
One of the problem which leads to lower efficiency is the deterioration in addition to huge loss in industry.

Many researches and conclusions have been put to treat such problem during the last development of such researches, this study was based on preparation of some 1, 3, 4-Thiadiazoles derivatives.

Cooling fluids are solutions or emulsions often prepared from mineral or artificial oils re used in the mechanical works like cutting and smoothing, the first use of these kinds of oils goes back to 200 years ago; those oils were used alone at that time by putting brush on the cutting tool.

The used oils originally from animal fats such as pigs and sharks. These types' fats didn't fulfill the purpose when the cutting is

acute, and the works were not on wide use as its now days. These are called welting agent (meaning materials which help by wet- ting the surface for the cutting material) once again with original material, because of the high temperature. This phenomenon known as microscopic welding (1).

Cooling fluids has two main jobs the first one is oiling and the other is cooling. Oiling is the main operation in the field in which the friction of the cutting tool with the metal, which is used to cut would generate a high heat which known as the external friction, which considered to be a percentage of one third from the total generated heat, and this is another heat which results also from the resistance of the cutting metal part and that active under the effect of the cutting tool, this called the internal friction, and the heat yield from this is $2 / 3$.

So the cooling fluids make to reduce from these yields heats by facilitate the slipping of the cutting tool. The second advantage is the cooling by reducing the yield heat in the metal piece be- 
cause the rise in the temperature of the metal piece will reduce the work efficiency and accuracy. There are several commercial types of the used cutting oils; the most wide used oils are the oils that have the ability to mix with water in which these oils may be artificial or semi-artificial and it goes by $90 \%$ from the uses.

There is no a doubting that the water alone is considered to be cooling fluid but its ability for oiling are almost nothing. While the oil alone is a fluid that has a low ability for cooling but it has high ability for oiling, so that the cooling oil is a mixture from both water and oil.

Although using oil alone can be cooling fluid but the addition of oil to water would give many advantages such as ${ }^{(1)}$ :

1- Prevents the formation of rust.

2- Can absorb the heat from the cutting part.

3- Help to remove impurities and particles.
4- Help to prevent the corrosions.

\section{Types of cooling fluids:}

There are at least five types of cooling fluids.

1- Oil-based cutting fluids.

2- Soluble oils with conc. 60$90 \%$ petroleum oils.

3- Chemical cutting fluids.

4- Synthetic non petroleum oils.

5- Synthetic $20-30 \%$ petroleum oils.

The soluble oil with conc. 6090\% petroleum oils are used in this research.

This soluble oil are called emulsion or the oil that have the ability to be emulsified, and some times known as oils that have the ability to make emulsion in water and also contain petroleum oil or mineral oil and emulsifying additives agents between 60$90 \%$.

Oil and water mixed to form cooling fluid, which has fixed 
features. Emulsifying agent help to the cutting metal piece during the work, these emulsifiers give the milky color of the fluid ${ }^{(2)}$.

\section{Types of water and its effect on}

\section{cooling fluids:}

The purity of water is the most important factor that controls the success or the fail of the cooling fluid.

The water which is used must be very pure, although any other types of water can be used for this purpose, so hard or salt water could be used but with unfavorable results because it ${ }^{(3)}$ :

1- Effects on the type of the yield quantity in which it will lower from the production efficiency.

2- Increases the conservation cost for the machines because it will expose to corrosions.

3 - Precipitate the particles in the machine parts.

4- Increases the growth of microorganisms.
5- Decreasing in the life of the cooling fluid.

\section{Why cooling fluid would be dete- riorate:}

Cooling fluid does not deteriorate without any causing. The cause of deterioration for cooling fluid is the growth of many kinds of micro organisms such as: bacteria, fungi, yeast and another micro organism, the other cause is mixing the cooling fluids with the lubricant oils and the metal particles, in which one could see the growth of which effects on the oiling efficiency and makes the deterioration.

Bacteria and fungi are founded in the cooling fluid by the causes of (4):

1- Finding the bacteria and the other microorganisms naturally in the useful water that used in synthesis of cooling fluids.

2- Deterioration of cooling fluids by microorganisms that comes from workers hands or saliva. 
3- Deterioration the fluids from the air of the factory for the laboratory.

The changes that take place on the cooling fluids because of microorganisms ${ }^{(5)}$ :

1- Changing the $\mathrm{pH}$ as well as the bad smells because of the formation of $\mathrm{H}_{2} \mathrm{~S}$ gas.

2- Decreasing the cooling fluids efficiency as well as the additives specially the anti corrosion compounds.

3- The emulsion will be separated.

4- At these conditions the microorganisms will secret organic acids which help to increase the corrosion.

5- The gases that result from the deterioration will also hurt the workers by a respiration tract infection and the skin infection.
6- Decreasing in the quality of the yields metal as well as decreasing in the age of the cutting tool.

\section{Aim of the work:}

Cooling fluids are playing an important role in the industrial processes through metals cutting. One of the problem which leads to lower efficiency is the deterioration in addition to huge loss in industry. Many researches and conclusions have been put to treat such problem during the last decade through using the antimicrobial agents. In order to participate the development of such researches, this study was passed on preparation of thiadiazole derivatives of the following structural formula: 


\section{Journal of Petroleum Researches \& Studies}<smiles>Nc1nnc(SSCC(N)C(=O)O)s1</smiles><smiles>O=C(O)CSSc1nnc(NC(=O)OC(Cl)Cl)s1</smiles><smiles>Nc1nnc(SSCC(=O)O)s1</smiles>

Compound (1),

Compound (2),

And using them as antimicrobial agents against some of microorganisms that cause the deteriorations.

\section{Experimental part:}

\section{Equipment and apparatus:}

The following equipment and apparatus were used throughout the study:-

\begin{tabular}{|c|c|}
\hline Apparatus & Company \\
\hline Sterilizer autoclave & Tomy (Japan) \\
\hline Incubator & Gallen Kamp (England) \\
\hline Shaker Incubator & GFI (England) \\
\hline Refrigeration & National(Japan) \\
\hline Hotplate with magnetic stirrer & scientific(England) \\
\hline Oven & Sanyo(Japan) \\
\hline pH-meter & Mettler-toledo(Switzerland) \\
\hline Infra red Spectrometer & FT- Shimatsu(Japan) \\
\hline Turbidity meter & Stuart scientific(England) \\
\hline Micropipettes & Volac(England) \\
\hline Melting point instrument & Sanyo(Japan) \\
\hline
\end{tabular}




\section{Chemicals and Biological materials:}

The chemicals and biological materials used in this study are the following:

\begin{tabular}{|c|c|c|}
\hline Chem. Comp. & State & Company \\
\hline Carbon disulfide & Solid & $\begin{array}{l}\text { Riedel-DeHaeny- } \\
\text { Germany }\end{array}$ \\
\hline Thiosemicarbazide & Solid & BDH-England \\
\hline Thioacetimide & Solid & Hopkin \& Williams \\
\hline L-Cysteine & Solid & BDH-England \\
\hline Chloro acetic acids & Solid & BDH-England \\
\hline Ethyl chloroformate & Liquid & MERK \\
\hline Absolute ethanol & Liquid & MERK \\
\hline Hydrochloric acid & Liquid & BDH-England \\
\hline Hydrogen peroxide & Liquid & MERK \\
\hline $\mathrm{KH}_{2} \mathrm{PO}_{4}$ & Solid & BDH-England \\
\hline $\mathrm{K}_{2} \mathrm{HPO}_{4}$ & Solid & BDH-England \\
\hline $\mathrm{MgSO}_{4} .7 \mathrm{H}_{2} \mathrm{O}$ & Solid & BDH-England \\
\hline $\mathrm{Co}\left(\mathrm{NO}_{3}\right)_{2} .6 \mathrm{H}_{2} \mathrm{O}$ & Solid & BDH-England \\
\hline $\mathrm{CuSO}_{4} .5 \mathrm{H}_{2} \mathrm{O}$ & Solid & BDH-England \\
\hline $\mathrm{MnSO}_{4} .4 \mathrm{H}_{2} \mathrm{O}$ & Solid & $\begin{array}{c}\text { BDH } \\
\text {-England }\end{array}$ \\
\hline $\mathrm{FeSO}_{4} .7 \mathrm{H}_{2} \mathrm{O}$ & Solid & BDH-England \\
\hline $\mathrm{NH}_{4} \mathrm{Cl}$ & Solid & Solid FluKa-Switzerland \\
\hline $\mathrm{NiSO}_{4} .7 \mathrm{H}_{2} \mathrm{O}$ & Solid & Solid FluKa-Switzerland \\
\hline $\mathrm{H}_{3} \mathrm{BO}_{4}($ Boric acid $)$ & Solid & Solid FluKa-Switzerland \\
\hline $\mathrm{ZnSO}_{4} .7 \mathrm{H}_{2} \mathrm{O}$ & Solid & Solid FluKa-Switzerland \\
\hline $\mathrm{CaNO}_{3} .4 \mathrm{H}_{2} \mathrm{O}$ & Solid & Solid FluKa-Switzerland \\
\hline Nutrient agar & Solid & Solid FluKa-Switzerland \\
\hline
\end{tabular}




\section{Preparation of 5-amino-1,3,4-thiadiazole-2-thiol (compound $\mathrm{A}$ ):}

5-amino-1,3,4-thiadiazole-2-thiol compound A was prepared by the method adopted by petrow and co-workers ${ }^{(6)}$ as follows:

Thiosemicarbazide $(0.3$ mole, $27.3 \mathrm{~g})$ was suspended in absolute ethanol $(105 \mathrm{ml})$, anhydrous sodium carbonate $(15.9 \mathrm{~g})$ and carbon disulfide (0.36 mole, 27.6 g) were then added and the mixture was refluxed with stirring for 6 hrs. The reaction mixture was then allowed tocool to room temperature and filtered. The filtrate was evaporated to dryness under reduced pressure and the residue was dissolved in distilled water (600 $\mathrm{ml})$ and acidified to $\mathrm{pH} 6$ with conc. $\mathrm{HCl}$ to give an orange precipitate. The crude product was filtered, washed excessively with distilled water and recrystallized from hot water to give compound $\mathrm{A}$ as yellow needles like the following structure:<smiles>Nc1nnc(S)s1</smiles>

Compound (A) 


\section{Preparation of bis (5-amino-1, 3, 4-thiadiazole-2-yl) disulfide}

\section{(compound B):}

This compound was pre-

pared by oxidation of com-

pound A using hydrogen peroxide $^{(7)}$.

Hydrogen peroxide $(31 \mathrm{ml}$, $3 \% \mathrm{~W} / \mathrm{V}$ ) was added dropwise to a solution of compound $\mathrm{A}$ $(45.8 \mathrm{ml}, 6 \mathrm{~g})$ in ethanol $(50$ ml) with continuous stirring for $1 \mathrm{hr}$ at room temperature. A yellow precipitate was formed, and this was collected by filtration, washed with distilled water and dried in oven at $70{ }^{\circ} \mathrm{C}$ to provide compound B like the following structure:<smiles>Nc1nnc(SSc2nnc(N)s2)s1</smiles>

Compound (B)

\section{Preparation of 2-amino-3-[(2-amino- 1,3,4, thiadiazol-5- yl)dithio]}

\section{propenoic acid (compound 1):}

This compound was pre-

pared by the general procedure of thiol-disulfide interchange method ${ }^{(8,9)}$.

An aqueos solution $(30 \mathrm{ml})$

containing L-cysteine (19.9

mmole, 2.42g) and potassium

hydroxide $\quad(39.8$ mmole,
$2.22 \mathrm{~g}$ ) adjusted to $\mathrm{pH} 7.5$, was added to a yellowish suspension of compound B (15.3 mmole, $4 \mathrm{~g}$ ) in potassium chloride $(30 \mathrm{ml}, 2 \mathrm{~N})$ at $\mathrm{pH} 7.5$. The reaction mixture was stirred continuously for $1 \mathrm{hr}$ at room temperature. A white precipitate was formed, and 


\section{Journal of Petroleum Researches \& Studies}

this was filtered, washed with

oven at $70{ }^{\circ} \mathrm{C}$ like the follow-

distilled water and dried in an ing structure:

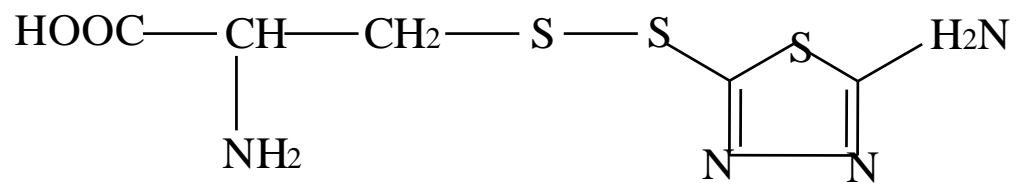

Compound (1)

\section{Preparation of 2-carboethoxyamino-5-mercapto-1,3,4-thiadiazole}

\section{(compound C):}

$T_{\text {his }}$ compound was pre-

The mixture was diluted with cold distilled water (50 pared by reaction of ethyl $\mathrm{ml}$ ) and acidified with diluted chlorofoprmate with compound A in Pyridine ${ }^{(10)}$. Ethyl chlorofoprmate (30 mmole, $3.3 \mathrm{~g}$ ) was added dropwise to a solution of compound $\mathrm{A}$ in pyridine $(11 \mathrm{ml})$ with continuous stirring at room temperature for $1 \mathrm{hr}$. hydrochloric acid to $\mathrm{pH} 3$. A pale yellow precipitate was formed, collected by filtration, washed excessively with cold distilled water and dried in an oven at $70{ }^{\circ} \mathrm{C}$. Compound $\mathrm{C}$ was obtained like the following structure:<smiles>CCC(=O)Nc1ccc(S)s1</smiles>

Compound (C) 


\section{Preparation of 2-(2-carbethoxyamino-1,3,4-thiadiazole-yl)-thio acetic}

\section{acid (compound 2):}

$T_{\text {his }}$ compound was pre-

pared by general procedure, S-alkylation ${ }^{(11)}$ of a thiolate salt with an alkyl halide.

To a solution of compound $\mathrm{C}$ (14.68 mmole, 3g) and chloro acetic acid (14.68 mmole, $1,4 \mathrm{~g})$ in $30 \mathrm{ml}$ of rectified spirit, $5.7 \mathrm{ml}$ of potassium hydroxide $(5 \mathrm{~N})$ was added. The reaction mixture was heated under reflex for $2 \mathrm{hrs}$. The hot solution was filtered to separate any insoluble materials and the ethanolic solution was evaporated under reduced pressure. The resdiue was dissolved in distilled water $(50 \mathrm{ml})$, acidified collecting fiteration washed with cold diditted water and dried in an oven at $70{ }^{\circ} \mathrm{C}$ to provide compound 2 .<smiles>O=C(O)CSSc1nnc(NC(=O)OC(Cl)Cl)s1</smiles>

Compound (2)

\section{Preparation of [ 5-amino-1,3,4-thiadiazol-2-yl)thio]acetic acid (com-}

\section{pound 3):}

This compound was pre-

pared from compound $\mathrm{A}$ and chloro acetic acid by a general procedure, S-alkylation of a thiolate salt with an alkyl ha- lide as described previously. The following concentrations of materials and catalysts were used:

Compound A (5 mmole, $0.666 \mathrm{~g})$, chloro acetic acid (5 


\section{Journal of Petroleum Researches \& Studies}

mmole, $1 \mathrm{gm}) 30 \mathrm{ml}$ of rectisium hydroxide $(5 \mathrm{~N})$ like the fied spirit, $5.7 \mathrm{ml}$ of potas-

following structure:

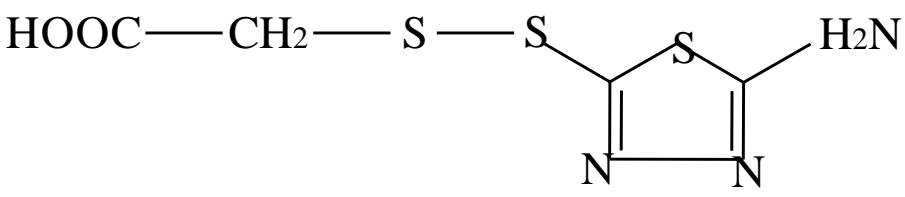

Compound (3)

\section{The Biological Part:}

\section{Salts Media:}

Mineral salts medium (Uchiyma et al., 1988) ${ }^{(12)}$ and $\mathrm{pH}$ was adjusted to $\mathrm{pH}$ (7.2-7.3), and then sterilized by Autoclaving at $121 \mathrm{AC}$ for $15 \mathrm{minu}-$ ets:

\begin{tabular}{|c|c|}
\hline Salt & Weigh / g \\
\hline $\mathrm{KH}_{2} \mathrm{PO}_{4}$ & 0.121 \\
\hline $\mathrm{K}_{2} \mathrm{HPO}_{4}$ & 1.170 \\
\hline $\mathrm{MgSO}_{4} .7 \mathrm{H}_{2} \mathrm{O}$ & 0.121 \\
\hline $\mathrm{Co}\left(\mathrm{NO}_{3}\right)_{2} .6 \mathrm{H}_{2} \mathrm{O}$ & 2.14 \\
\hline $\mathrm{CuSO} 4.5 \mathrm{H}_{2} \mathrm{O}$ & 0.48 \\
\hline $\mathrm{MnSO}_{4} .4 \mathrm{H}_{2} \mathrm{O}$ & 0.28 \\
\hline $\mathrm{FeSO}_{4} .7 \mathrm{H}_{2} \mathrm{O}$ & 0.06 \\
\hline $\mathrm{NH}_{4} \mathrm{Cl}$ & 0.001 \\
\hline $\mathrm{NiSO}_{4} .7 \mathrm{H}_{2} \mathrm{O}$ & 0.005 \\
\hline $\mathrm{H}_{3} \mathrm{BO}_{4}\left(\mathrm{Boric}_{2} \mathrm{acid}\right)$ & 0.01 \\
\hline $\mathrm{ZnSO}_{4} .7 \mathrm{H}_{2} \mathrm{O}$ & 0.0061 \\
\hline $\mathrm{CaNO}_{3} .4 \mathrm{H}_{2} \mathrm{O}$ & 0.00006 \\
\hline
\end{tabular}




\section{Journal of Petroleum Researches \& Studies $\quad \begin{gathered}\mathrm{N}_{\mathrm{O}} .2 \\ 2^{\text {nd. }} \text { YEAR }\end{gathered}$}

\section{Nutrient agar:}

Nutrient agar was prepared as recommended by manufacturing company and sterilized by $\mathrm{Au}$ toclaving at $121 \mathrm{AC}$ for $15 \mathrm{minu}-$ ets.

\section{Growth of bacteria strain:}

Mineral salt medium was used to grow the bacteria and the aeration of liquid culture was best achieved by incubating the flask in shaker incubator at $150 \mathrm{rpm}$ for 6 days at $37^{\circ} \mathrm{C}$. After that $100 \mu 1$ added from the emulsion samples of 1 day, 1 week and 2 weeks after using to the mineral salts in conical flasks.

Then these conical flasks incubated in the incubator for 6 days. After that the $\mathrm{pH}$ and the turbidity measured.

Preparing different concentrations of the compound 1 in the mineral salts media, after the growth of bacteria, the solution $(0.1 \mathrm{~g} / 10 \mathrm{ml}$ ethanol $)$ from com- pound 1 used to prepare the following concentrations that added to the conical flasks which contains $25 \mathrm{ml}$ of mineral salts media with $100 \mu$ l of the emulsion sample: 


\begin{tabular}{|c|c|c|}
\hline Conical flask no. & $\begin{array}{c}\text { Vol. of added solu- } \\
\text { tion/ml }\end{array}$ & $\begin{array}{c}\text { Concentration } \\
\mu \mathrm{g} / \mathrm{ml}\end{array}$ \\
\hline 1 & 0 & 0 \\
\hline 2 & 0.5 & 100 \\
\hline 3 & 1 & 200 \\
\hline 4 & 1.5 & 300 \\
\hline 5 & 2 & 400 \\
\hline 6 & 2.5 & 500 \\
\hline
\end{tabular}

- $\mathrm{pH}$ standardization has been made for each conical flask.

- Measuring the $\mathrm{pH}$ for the conical flasks before addition different concentrations of the compound1.

- After addition inhibitor the conical flasks are kept in the incubator at $37^{\circ} \mathrm{C}$ for 48 hours.

- The $\mathrm{pH}$ was measured to the 6 conical flasks after incubation period.

- The turbidity was measured by Turbidity meter to the 6 conical flasks.
- $10 \mu \mathrm{l}$ of control (sample emulsion) has been taken and $90 \mu \mathrm{l}$ of sterilized normal saline was added in epindorf tube. This process has been mad for each of the 6 conical flasks.

- $10 \mu 1$ from each epindorf tube has been taken and addad to the 6 petridishes that contain the nutrient agar, and spread it carefully by sterilized spreader.

- The above procedure was repeated for each inhibitor (compounds 2and 3) which has been used. 


\section{Results and discussions:}

Thiadiazole derivatives have been found to have a wide range of applications; one of these applications is in the field of organic pharmaceutical chemistry due to the ability of these derivatives to kill different microorganisms. This work included the preparation of three heterocyclic com pounds containing thiadiazole moiety. They were characterized by I.R. spectroscopy and melting point. This will be described in the first part of this work. The second part will deal with the biological activity of the prepared compounds on the cooling fluids with different methods.
Preparation of Thiadiazole de-

\section{rivatives}

Good yield and purer products were produced in this work in which compound A was prepared according to the method described by petrow ${ }^{(6)}$, through the reaction of thiosemicarbazide with carbon disulfide in the presence of anhydrous sodium carbonate in absolute ethanol. The structure of compound A was confirmed by its melting points 232-233 ${ }^{\circ} \mathrm{C}$, while the reported melting point is $232{ }^{\circ} \mathrm{C}^{(13)}$.

Compound $\mathrm{B}$ was prepared by oxidation of compound A with hydrogen peroxide in alcoholic medium, and the structure of compound $\mathrm{B}$ was confirmed by comparing its melting point (244- $245^{\circ} \mathrm{C}$ ) to the reported 245 ${ }^{\circ} \mathrm{C}^{(14)}$.

Compound 1 was prepared by the general procedure of thioldisulfide interchange reaction 


\section{Journal of Petroleum Researches \& Studies}

$\mathrm{No}_{\mathrm{O}} \cdot 2$

$2^{\text {nd. }}$ YEAR

through the reaction of thiolate anion of cysteine and thio acetic acid respectively with compound $\mathrm{B}$ in aqueous medium at $\mathrm{pH}$ $7.5^{(8,9)}$.

The structure of compound 1 was confirmed by measuring its melting point 249-251and by I.R. spectrum which showed the following characteristics absorption bands $\left(\mathrm{KBr}\right.$ disc $\left.\mathrm{cm}^{-1}\right), 3440$ 3405 (N-H str. Of amine), 31252000 (broad with multiple band of $\mathrm{NH}_{3}$ str. $) 1645(\mathrm{C}=\mathrm{N})$ str., at $\left(1562 \mathrm{~cm}^{-1}\right)$, and $\left(1400 \mathrm{~cm}^{-1}\right)$ for carboxylate ion stretching vibrations respectively $\left(1275 \mathrm{~cm}^{-1}\right)(\mathrm{C}$ O) str., $\left(1150 \mathrm{~cm}^{-1}\right)(\mathrm{C}-\mathrm{N})$ stretching like the following spectrum figure:

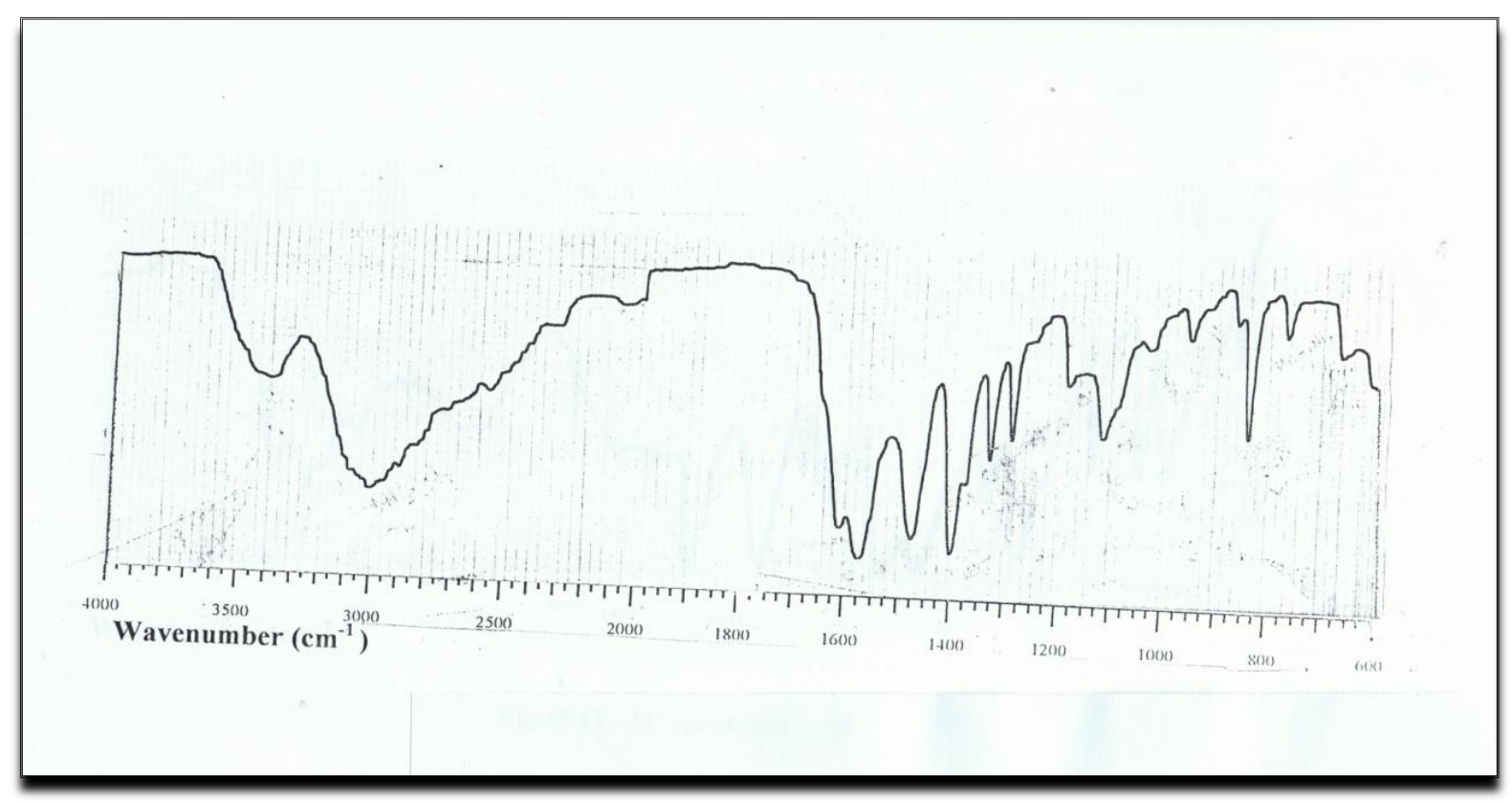

Figure (1): showed the I.R. spectrum of compound 1 


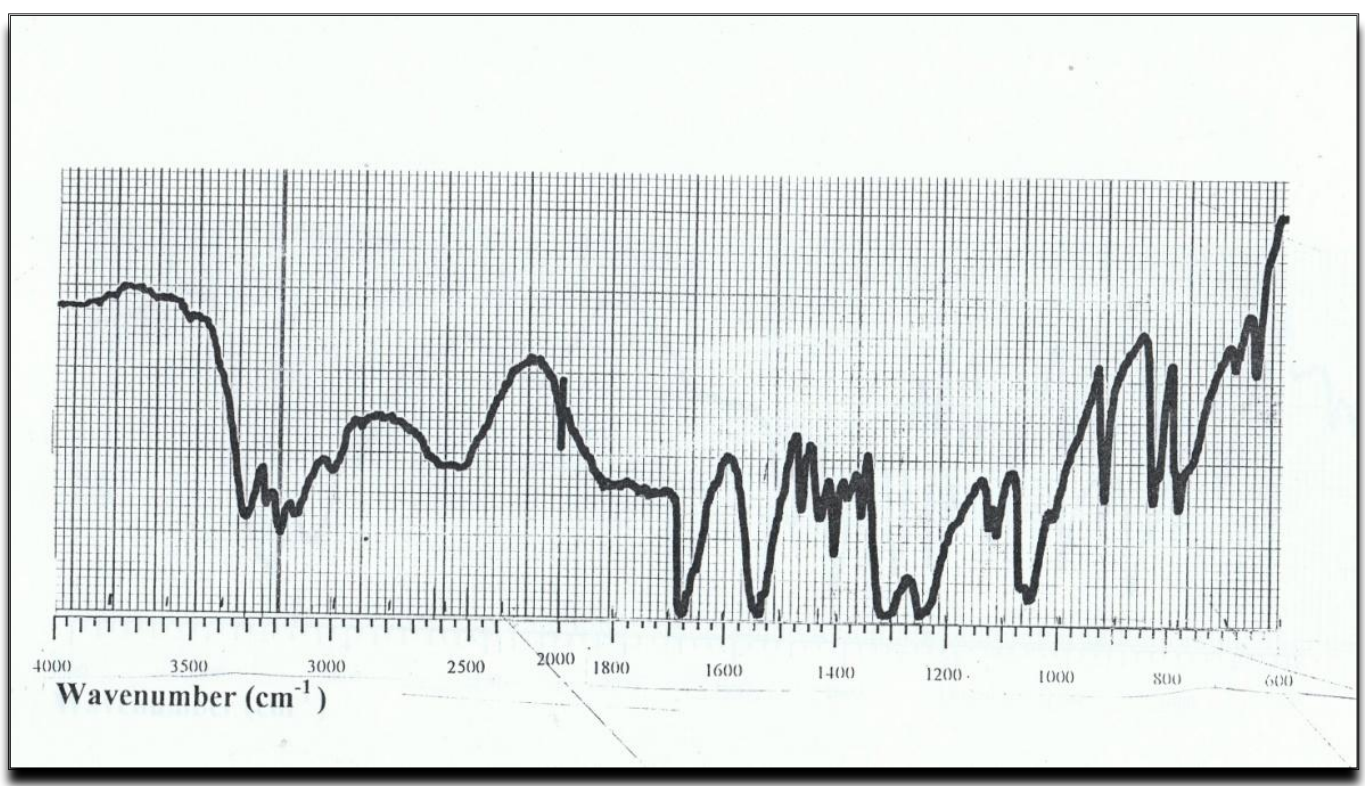

Compound 3 was prepared by the same procedure used to prepare compound 2 except that the reaction was carried out between compound $\mathrm{A}$ and chloro acetic acid.

The structure of compound 3 was confirmed by measuring the melting point (207-208 $\left.{ }^{\circ} \mathrm{C}\right)$ with I.R. spectrum which showed the following absorp- tion bands: $\left(\mathrm{KBr}\right.$ disc $\left.\mathrm{cm}^{-1}\right)$, $3345 \mathrm{~cm}^{-1}, 3280 \mathrm{~cm}^{-1}(\mathrm{~N}-\mathrm{H}$ asymmetric and symmetric str.), $3127 \mathrm{~cm}^{-1}$ (O-H str.), $2948 \mathrm{~cm}^{-1}$ (C-H str.), $1700 \mathrm{~cm}^{-}$ ${ }^{1}$ ( $\mathrm{C}=\mathrm{O}$ str. Of the acid), 1618 $\mathrm{cm}^{-1}$ (C=N str.), $\quad 1520$ $\mathrm{cm}^{-1}$ (N-H bending), $1220 \mathrm{~cm}^{-}$ ${ }^{1}$ (C-O str.), and $1100 \mathrm{~cm}^{-1}$ (C$\mathrm{N}$ str.) like the following spectrum figure: 


\section{Journal of Petroleum Researches \& Studies $\quad \frac{N_{0} \text { No.2 }^{\text {nd. }} \text { YEAR }}{2}$}

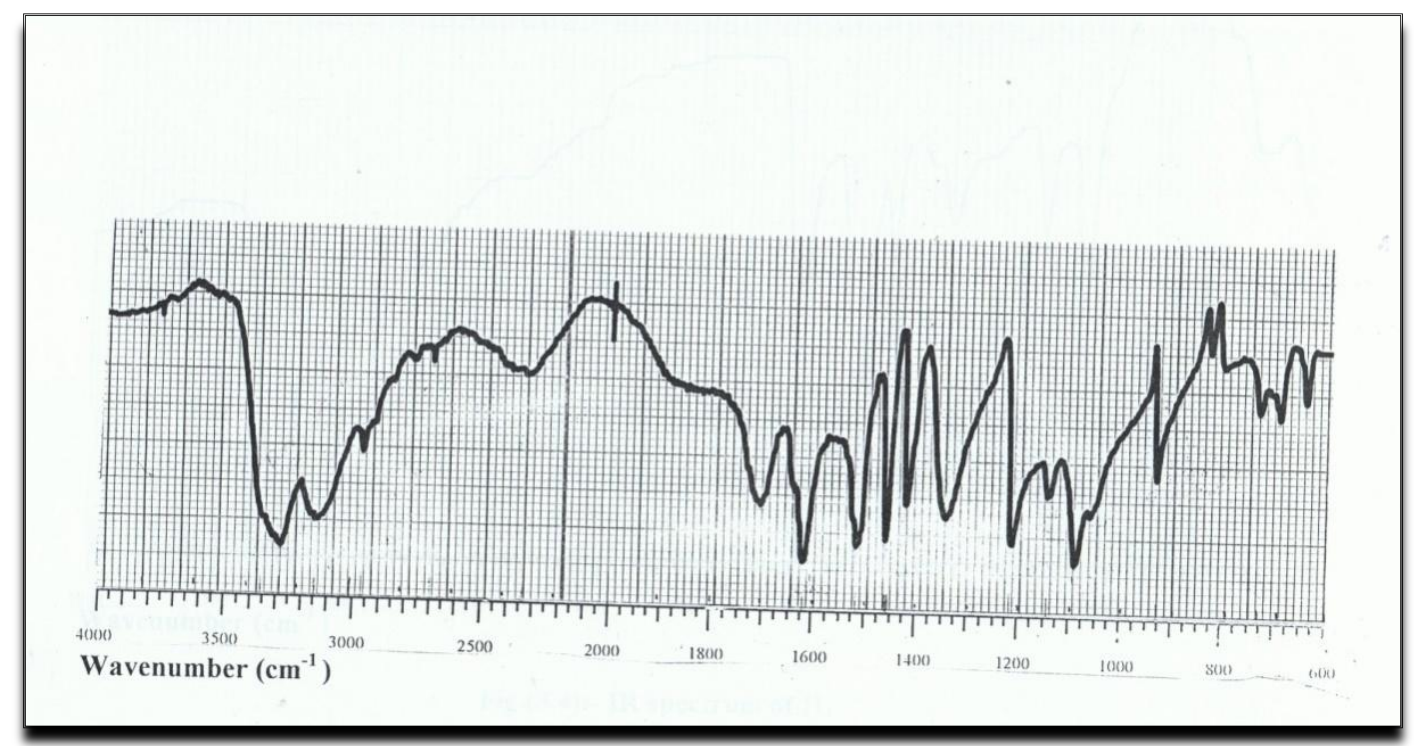

Figure (3): showed the I.R. spectrum of compound 3

Table (1)

Physical Data the synthesized thiadiazoles compounds

\begin{tabular}{|c|c|c|c|c|c|c|}
\hline \multirow{2}{*}{$\begin{array}{c}\text { Symbol/Chemical } \\
\text { Formula }\end{array}$} & \multirow{2}{*}{$\begin{array}{l}\text { Reaction } \\
\text { Solvent }\end{array}$} & \multirow{2}{*}{$\begin{array}{c}\text { Recrrystillization } \\
\text { Solvent }\end{array}$} & \multirow{2}{*}{ Color } & \multirow{2}{*}{$\begin{array}{c}\% \\
\text { Yield }\end{array}$} & \multicolumn{2}{|c|}{ Melting point } \\
\hline & & & & & Absorved & Reported \\
\hline A & Ethanol & Water & $\begin{array}{l}\text { Pale } \\
\text { Yellow }\end{array}$ & 68 & 232-233 & 232 \\
\hline B & Ethanol & - & Yellow & 82 & $244-245$ & 245 \\
\hline $\mathrm{C}$ & Pyridine & Water & White & 81 & 204-205 & 204-205 \\
\hline $\begin{array}{c}1 \\
\mathrm{C}_{5} \mathrm{H}_{9} \mathrm{O}_{2} \mathrm{~N}_{4} \mathrm{~S}_{3}\end{array}$ & Water & Ethanol/Water & White & 85 & 249-251 & \\
\hline $\begin{array}{c}2 \\
\mathrm{C}_{7} \mathrm{H}_{9} \mathrm{O}_{4} \mathrm{~N}_{3} \mathrm{~S}_{2}\end{array}$ & Ethanol & Ethanol/Water & White & 84 & 173-175 & \\
\hline $\begin{array}{c}3 \\
\mathrm{C}_{4} \mathrm{H}_{5} \mathrm{O}_{2} \mathrm{~N}_{3} \mathrm{~S}_{2}\end{array}$ & Ethanol & Water & Yellow & 79 & 207-208 & \\
\hline
\end{tabular}


The Biological activity Part:

The synthesized compounds have been used as antimicrobial against the microorganisms which have been found in the cooling fluids that has been taken from the Chemical Central Research and Petrochemical Industries.

The biological activity of these synthesized compounds has been measured by three methods:

\section{1-Measuring the Turbidity:}

The three types of samples for the fluid taken from the laboratory of the industry in different time uses, and to estimate which one of the three samples has most deteriorated a standardization process has been made to measure the turbidity and $\mathrm{pH}$ after adding $100 \mu \mathrm{l}$ from each emulsion samples to the mineral salts media with incubation time, the results are shown in the following tables:

Table (2)

This table shows the effect of the using time of the emulsion on the turbidity and emulsion type of it.

\begin{tabular}{|c|c|c|c|}
\hline Sample no. & $\begin{array}{c}\text { Emulsion } \\
\text { Type }\end{array}$ & Used Time & Turbidity/NTU \\
\hline 1 & White & 1 Day & 678 \\
\hline 2 & Semi-Turbid & 7 Days & 227 \\
\hline 3 & Turbid & 14 Days & 45 \\
\hline
\end{tabular}


Table (3)

This Table shows the effect of the using time of the emulsion on the $\mathrm{pH}$ and emulsion type of it

\begin{tabular}{|c|c|c|c|}
\hline Sample no. & $\begin{array}{c}\text { Emulsion } \\
\text { Type }\end{array}$ & Used Time & $\mathbf{p H}$ \\
\hline 1 & White & 1 Day & 7.09 \\
\hline 2 & Semi-Turbid & 7 Days & 6.83 \\
\hline 3 & Turbid & 14 Days & 6.58 \\
\hline
\end{tabular}

From these data above we conclude that sample no. 3 is more deteriorated than the others $(1$, 2), therefore this sample was used in measuring the biological activity of the synthesized compounds.

The synthesized compounds $(1,2,3)$ have been tested as antibacteria in the cooling fluid of the most deteriorated sample (2week) in different concentrations, then the turbidity and $\mathrm{pH}$ values were measured as been shown in the following tables: 
a. Measuring the turbidity for the sample of two week ago after addition the compound 1as inhibitor in mineral salts media

\begin{tabular}{|c|c|c|}
\hline Sample no. & $\begin{array}{c}\text { Concentration of } \\
\text { compound 1 / } \\
\text { ppm }\end{array}$ & $\begin{array}{c}\text { Turbidity in } \\
\text { NTU }\end{array}$ \\
\hline 1 & 0 & 53 \\
\hline 2 & 100 & 92 \\
\hline 3 & 200 & 184 \\
\hline 4 & 300 & 297 \\
\hline 5 & 400 & 472 \\
\hline 6 & 500 & 664 \\
\hline
\end{tabular}

b. Measuring the turbidity for the sample of two week ago after addition the compound 2 as inhibitor in mineral salts media.

\begin{tabular}{|c|c|c|}
\hline Sample no. & $\begin{array}{c}\text { Concentration of- } \\
\text { compound 2 / } \\
\text { ppm }\end{array}$ & $\begin{array}{c}\text { Turbidity in } \\
\text { NTU }\end{array}$ \\
\hline 1 & 0 & 45 \\
\hline 2 & 100 & 82 \\
\hline 3 & 200 & 174 \\
\hline 4 & 300 & 287 \\
\hline 5 & 400 & 442 \\
\hline 6 & 500 & 652 \\
\hline
\end{tabular}


c. Measuring the turbidity for the sample of two week ago after addition the compound 3 as inhibitor in mineral salts media.

\begin{tabular}{|c|c|c|}
\hline Sample no. & $\begin{array}{c}\text { Concentration of } \\
\text { compound 3 / } \\
\text { ppm }\end{array}$ & $\begin{array}{c}\text { Turbidity in } \\
\text { NTU }\end{array}$ \\
\hline 1 & 0 & 85 \\
\hline 2 & 100 & 212 \\
\hline 3 & 200 & 380 \\
\hline 4 & 300 & 428 \\
\hline 5 & 400 & 548 \\
\hline 6 & 500 & 672 \\
\hline
\end{tabular}

\section{2- Measuring the $\mathrm{pH}$ :}

In this research the $\mathrm{pH}$ has been measured because of growth the pseudomonas bac- teria in the cooling fluid that release the $\mathrm{H}_{2} \mathrm{~S}$, so whatever the $\mathrm{pH}$ decreased the growth of bacteria increased, like the following

a. Measuring the $\mathrm{pH}$ for the sample of two weeks ago after addition the compound 1 as inhibitor in mineral salts media.

\begin{tabular}{|c|c|}
\hline $\begin{array}{c}\text { Concentration of } \\
\text { Compound } \mathbf{1} \text { ppm }\end{array}$ & pH value \\
\hline 0 & 6.23 \\
\hline 100 & 6.38 \\
\hline 200 & 6.46 \\
\hline 300 & 6.61 \\
\hline 400 & 6.88 \\
\hline 500 & 7.07 \\
\hline
\end{tabular}


b. Measuring the $\mathrm{pH}$ for the sample of two weeks ago after addition the compound 2 as inhibitor in mineral salts media.

\begin{tabular}{|c|c|}
\hline $\begin{array}{c}\text { Concentration of } \\
\text { Compound } \mathbf{2} \text { ppm }\end{array}$ & pH value \\
\hline 0 & 6.20 \\
\hline 100 & 6.28 \\
\hline 200 & 6.37 \\
\hline 300 & 6.52 \\
\hline 400 & 6.65 \\
\hline 500 & 6.86 \\
\hline
\end{tabular}

c. Measuring the $\mathrm{pH}$ for the sample of two weeks ago after addition the compound 3 as inhibitor in mineral salts media.

\begin{tabular}{|c|c|}
\hline $\begin{array}{c}\text { Concentration of } \\
\text { Compound } \mathbf{3} \text {. ppm }\end{array}$ & pH value \\
\hline 0 & 6.24 \\
\hline 100 & 6.35 \\
\hline 200 & 6.47 \\
\hline 300 & 6.66 \\
\hline 400 & 6.87 \\
\hline 500 & 7.11 \\
\hline
\end{tabular}




\section{3- Culture method:}

a- Measuring the biological activity for the sample of two weeks a go after addition compound 1as inhibitor in mineral salts media, by using nutrient agar culture media

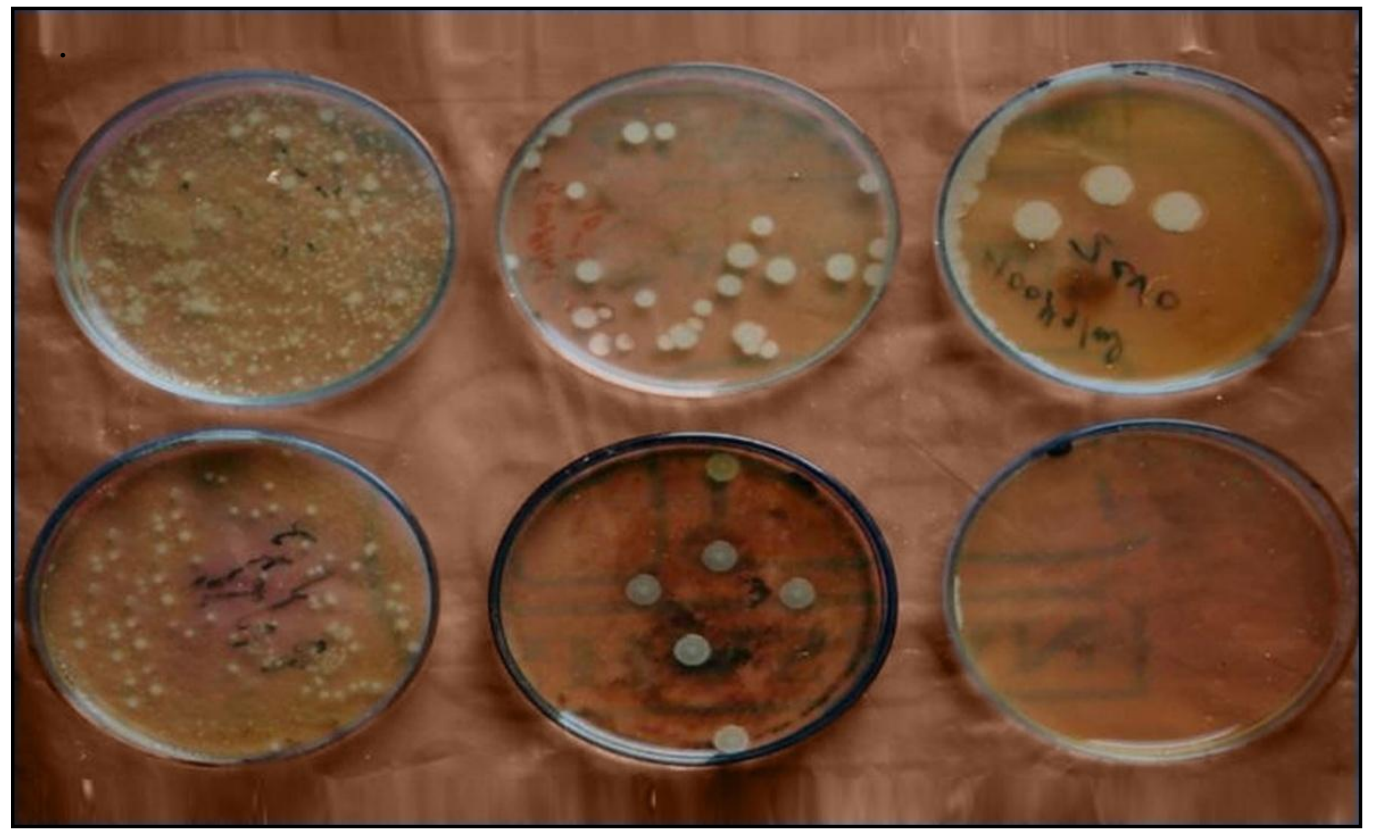

This picture represents the biological activity for the compound 1 to kill bacteria found in the cooling fluid in different concentrations. We notice that the first one from the left represents the control in which the concentration used for the compound 1 was 0 , so the bacteria were too much, while in the second one which is in the middle represent 300 ppm of the compound 1, so bacteria decreased here be- cause of the biological activity of compound 1 that kills bacteria, the third one which is in the right represents 500 ppm of the compound 1 , so the bacteria nearly disappeared here because of the high biological activity that kills bacteria.

In the lower part from the picture represent the diluted mineral salts media with the inhibitor in $10^{-1}$. 
b- Measuring the biological activity for the sample of two weeks a go after addition compound 1as inhibitor in mineral salts media, by using nutrient agar culture media.

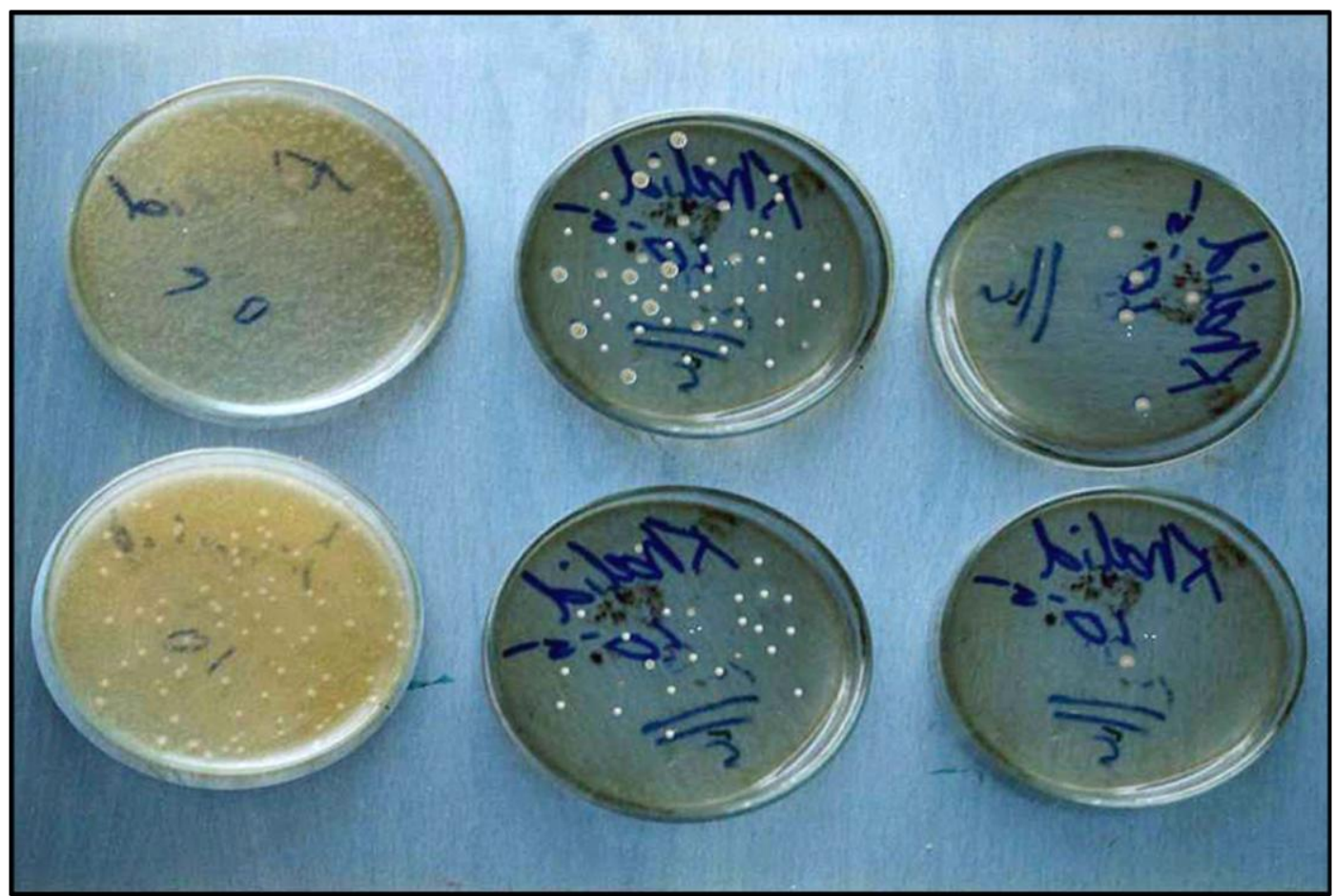

This picture represents the biological activity for the compound 2 to kill bacteria found in the cooling fluid in different concentrations. We notice that the first one from the left represents the control in which the concentration used for the compound 2 was 0 , so the bacteria were too much, while in the second one which is in the middle represent $300 \mathrm{ppm}$ of the compound 2 , so bacteria de- creased here because of the biological activity of compound 1 that kills bacteria, the third one which is in the right represents $500 \mathrm{ppm}$ of the compound 2 , so the bacteria nearly disappeared here because of the high biological activity that kills bacteria. In the lower part from the picture represent the diluted mineral salts media with the inhibitor in $10^{-1}$. 
c- Measuring the biological activity for the sample of two weeks a go after addition compound 3 as inhibitor in mineral salts media, by using nutrient agar culture media.

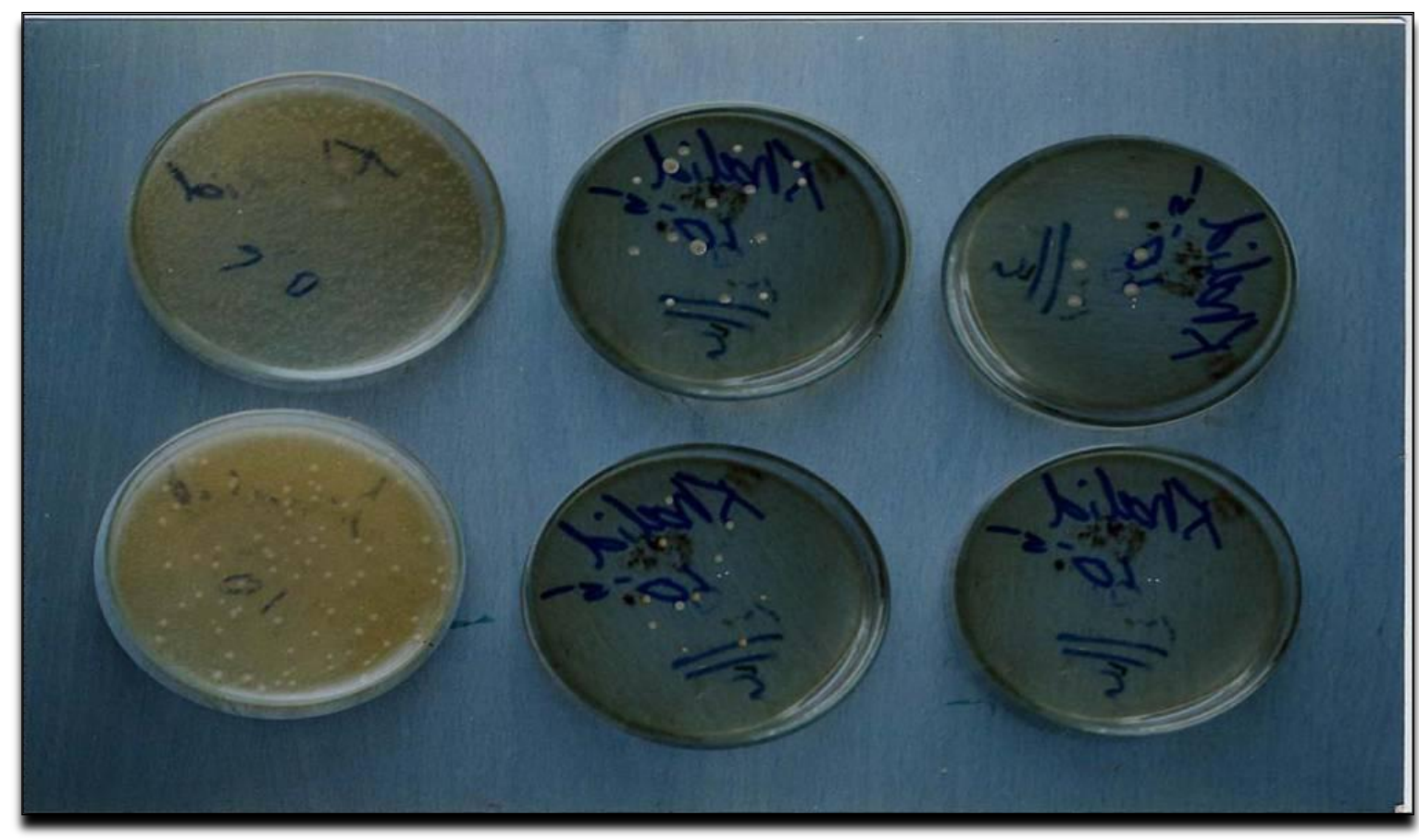

This picture represents the biological activity for the compound 3 to kill bacteria found in the cooling fluid in different concentrations. We notice that the first one from the left represents the control in which the concentration used for the compound 3 was 0 , so the bacteria were too much, while in the second one which is in the middle represent 300 ppm of the compound 3, so bacteria decreased here because of the biological activity of compound 3 that kills bacteria, the third one which is in the right represents 500 ppm of the compound 3, so the bacteria nearly disappeared here because of the high biological activity that kills bacteria. 
Table (4)

This table gives the percentage of killing for the microorganisms by the compounds $(1,2$, and 3$)$ in different concentrations.

\begin{tabular}{|c|c|c|c|c|c|}
\hline $\begin{array}{c}\text { Com- } \\
\text { pound } \\
\text { no. }\end{array}$ & $\begin{array}{c}\text { Control } \mathbf{1 0} \text { (10 } \\
\mathbf{1} \text { no. of sur- } \\
\text { viving mi- } \\
\text { croorganism }\end{array}$ & $\begin{array}{c}\mathbf{3 0 0} \mathbf{~ p p m ~ n o . ~} \\
\text { of surviving } \\
\text { microorgan- } \\
\text { isms }\end{array}$ & $\begin{array}{c}\text { Percen- } \\
\text { tage of } \\
\text { killing } \\
\text { for } \\
\mathbf{3 0 0 p p m}\end{array}$ & $\begin{array}{c}\mathbf{5 0 0} \mathbf{~ p p m ~ n o . ~} \\
\text { of surviving } \\
\text { microorgan- } \\
\text { isms }\end{array}$ & $\begin{array}{c}\text { Percen- } \\
\text { tage of } \\
\text { killing } \\
\text { for 500 } \\
\text { ppm }\end{array}$ \\
\hline $\mathbf{1}$ & 247 & 26 & $89.5 \%$ & 3 & $98.78 \%$ \\
\hline $\mathbf{2}$ & 235 & 50 & $78.72 \%$ & 5 & $97.87 \%$ \\
\hline $\mathbf{3}$ & 235 & 15 & $93.72 \%$ & 5 & $97.87 \%$ \\
\hline
\end{tabular}

We notice here from this table the no. of surviving microorganisms for each compound in different concentrations as well as the percentage of killing bacteria by using each synthesized compound.

We can see that whatever the concentration increased for each inhibitor compound the no. of surviving bacteria decreased and the percentage of killing microorganisms increased.

Also from these tables we can notice that the best percentages of killing for the microorganisms are the compounds 1 and 3 respectively. 


\section{References:}

1- Center of Hazardous Materials Research. Environmental Issues: Student manual. University of Pittsburgh Applied Research center, Pittsburgh, PA. p 3(1992).

2- Gabris T. "Emulsified Industrial oils Recycling". Energy conservation study,

3- DOE/BC/10183-1. U.S. Department of energy, Division of industrial energy conservation. Bartlesville, OK, pp: 101-104 (1982).

4- Howard, G. "Waste Minimization through coolant recycling. ME Technical paper presented at Technology for implementing and improving Waste minimization of industrial Fluids". Society of Manufacturing Engineers. Dearborn, MI. (1989).

5- Pallansch, J. "Machine coolant waste reduction by optimization coolant life". U.S. EPA, office of research and development, risk reduction engineering laboratory, Cincinnati. OH. (1989).

6- Loida, B., D. Peterson, and T.Foeck. "Machine Coolant Maintenance Leading to Waste Reduction". Minnesota Technical Assistance Program, Minneapolis. MN. (1989).

7- Petrow V., Stephanson O., Thomas A. J. amd Will A. M.; J Chem. Soc., 1508, (1958).

8- Gula A.; J. Amer. Chem. Soc., 44 1502, (1922).

9- Wilson J. M., Bayer R. J., and Huper D. J.; Ibid, 99, 7922, (1977).

10- Mcalan D. T., Cullum T. V., Dean R. A., and Filder F. A.; Ibid, 73, 3627, (1951).

10-A. I. Al-shather, M. Sc. Thesis, Baghdad University, Iraq, (2000).

11-Vogals ; " Text Book of Practical Organic Chemistry", pp584-585, (1978).

12- Unchiyama, H.; Nakajima, T.; Yagi, O. and Tabuchi, T. Aerobic degradation of trichloroethylene at high concentration by a methane-utilizing mixed culture. Agric. Biol. Chem. 53: pp1019-1024(1988). 


\section{Journal of Petroleum Researches \& Studies \\ $\mathrm{N}_{\mathrm{O}} .2$ \\ $2^{\text {nd. }}$ YEAR}

13-Bamabas L.L.;" Five membered heterocyclic compounds with Nitrogen and Sulfur, Sulfur and Oxygen (except thiazole), Interscience Publishers, New York, pp. 152, (1952).

14- M. H. Mohammed, M. Sc. Thesis, Baghdad University, Iraq, (1997) 
الاسم : خالـــــــليد زين العابدين

العنوان الوظيفي : مدرس مساعد / كلية العلوم .

1980: المواليا

موقع العمل :استاذ في كلية العلوم جامعة النهرين .

التحصيل الدراسي : ماجستير في الكيمياء الحياتية لعام2004 ـ . 